\title{
Infestation of Early- and Late-Flushing Trees by Spring Caterpillars: An Associational Effect of Neighbouring Trees
}

\author{
Lenka Sarvašová ${ }^{1, * \mathbb{C}}$, Peter Zach ${ }^{1}$, Michal Parák $^{2}$, Miroslav Saniga ${ }^{1}$ and Ján Kulfan ${ }^{1}$ \\ 1 Institute of Forest Ecology, Slovak Academy of Sciences, L'. Štúra 2, 96053 Zvolen, Slovakia; zach@ife.sk (P.Z.); \\ miro.saniga@gmail.com (M.S.); kulfan@ife.sk (J.K.) \\ 2 Independent Researcher, Banšelova 28, 82104 Bratislava, Slovakia; parcius23@gmail.com \\ * Correspondence: lenka.sarvasova14@gmail.com
}

check for

updates

Citation: Sarvašová, L.; Zach, P.; Parák, M.; Saniga, M.; Kulfan, J.

Infestation of Early- and

Late-Flushing Trees by Spring

Caterpillars: An Associational Effect of Neighbouring Trees. Forests 2021, 12, 1281. https://doi.org/10.3390/ f12091281

Academic Editor: Dariusz

J. Gwiazdowicz

Received: 26 August 2021

Accepted: 16 September 2021

Published: 18 September 2021

Publisher's Note: MDPI stays neutral with regard to jurisdictional claims in published maps and institutional affiliations.

Copyright: (c) 2021 by the authors. Licensee MDPI, Basel, Switzerland. This article is an open access article distributed under the terms and conditions of the Creative Commons Attribution (CC BY) license (https:/ / creativecommons.org/licenses/by/ $4.0 /)$.
Abstract: In temperate forests within Europe, early-flushing (EF) deciduous trees are often heavily infested by early spring leaf-eating Lepidoptera, while late-flushing (LF) trees are better protected in a phenological manner against such heavy infestations, as spring moth larvae begin to appear before their bud burst. The associational effects of EF trees on LF ones are only poorly known. We studied whether or not the infestation of LF trees by spring Lepidoptera can be affected by EF ones if they grow in the immediate vicinity. We compared spring assemblages of leaf-eating larvae of Lepidoptera on LF Quercus cerris L. with those on EF Q. pubescens Willd. in several microhabitats in Slovakia, Central Europe. Larvae were collected from mature and young trees. Mature trees sampled were growing: (1) in a closed-canopy forest; (2) in small groups; or (3) as a lone tree. Forest and tree groups are both constituted by oak species. Tree groups and lone trees were 20-50 m distant from forest edges. Young trees were growing (1) under mature $Q$. pubescens trees in a forest or (2) as a lone tree within forest gaps or near the edges. In the closed-canopy forest where LF trees (Q. cerris) were surrounded by EF ones ( $Q$. pubescens), the caterpillars on mature LF trees were in abundance, almost as on mature EF ones. The species composition of larval assemblages on the two oak species was similar. In contrast, on small groups and on lone trees, the lepidopteran larvae were significantly less abundant on LF trees than EF ones. In the case of young trees, the abundance of larvae and their composition assemblages on both oaks were comparable in the forest. In the open habitat, LF trees were less infested by larvae than EF ones and the assemblages of moth larvae differed between the two. Our results reveal the effect (associational susceptibility) of EF trees on LF ones when growing in a close vicinity. It means that the phenological protection of LF trees may not be sufficient if they grow close to or are surrounded by EF ones.

Keywords: associational susceptibility; Quercus; forest protection; phenological synchrony; Operophtera brumata; Agriopis leucophaearia; bud burst; herbivory

\section{Introduction}

In temperate European forests, many early-flushing (EF) deciduous trees host numerous species of spring-feeding caterpillars of Lepidoptera, among them well-known Operophtera brumata (Linnaeus, 1758), Erannis defoliaria (Clerck, 1759), Agriopis spp., Tortrix viridana (Linnaeus, 1758), Lymantria dispar (Linnaeus, 1758), etc. [1-12]. They often cause defoliation of woody plants in forests or fruit trees.

The successful development of these Lepidoptera depends on synchrony between the hatching of caterpillars and the bud burst of host trees [13-21]. Neonates from folivorous caterpillars of early spring Lepidoptera have access to suitable food if they hatch or activate after overwintering inside the narrow phenological window occurring right after the bud burst of their hosts. If they hatch too early-before the bud burst, they starve because flushing buds and young foliage are lacking $[14,19,22]$. Spring caterpillars can resist starvation only for a few days [14]. On the other hand, if they do it too 
late-relatively long after the bud burst, they also suffer from a lack of suitable food (i.e., young foliage) on host trees because the increased content of non- or low-digestible compounds and protective chemicals in maturing and mature leaves have a negative impact on caterpillar performance [19,23-29].

Caterpillars hatching early and late, which miss the window of opportunity for feeding on young foliage on the primary host tree (the one where they are born) need to locate food, usually on another tree. Baby caterpillars can achieve long-distance dispersal through ballooning - they use a silk thread or long setae on their bodies to float on air currents or to be borne by wind [30-38]. Caterpillars can leave unsuitable places also by lowering on a silk thread or dropping [31,39-41], or by walking from one tree to another where they touch each other [42].

The effects of woody plant diversity on herbivory in forests have often been studied with variable results [43-49]. Neighbouring trees can increase or decrease insect attacks to those that are at the centre (associational susceptibility or resistance) [50]. It is generally accepted that insect herbivory is lower in mixed forest stands than in pure stands, i.e., associational resistance e.g., [51-53]. However, many authors emphasise that beyond tree diversity per se, these effects are strongly dependent on the traits of host trees as well as the specificity of insect phytophages e.g., [51,53-57].

There is a little knowledge on fine-scale mechanisms leading to the associational effects of neighbouring plants on those that are at the centre [45,46,48,57-59]. For example, herbivores can move from one host plant to another neighbouring one [50]. There are few data on how EF trees affect the occurrence and abundance of spring caterpillars on late-flushing (LF) ones. Nealis and Régnière [60] recorded redistribution of late-instar caterpillars belonging to Choristoneura fumiferana Clemens, 1865, from damaged EF to undamaged LF host trees. Schafellner et al. [61] supposed that older caterpillars of Lymantria dispar left primary food places on Quercus petraea (Matt.) Liebl. trees and moved to young foliage on LF Q. cerris L. trees. Wesołowski and Rowiński [7] stated that LF oaks (Quercus robur L.) co-occurring with EF trees were visibly defoliated only during an outbreak.

Mixed deciduous forests comprising trees with various stages of bursting are widespread in temperate Europe [62-67]. We assume, therefore, that neighbourhood of early- and late-flushing co-occurring trees can significantly affect the infestation of the latter by spring Lepidoptera.

Studies on defoliators in fragmented forests or, in general insect herbivores in fragmented habitats, have brought conflicting results [47,68-71] which reflect the specific conditions of habitats (fragment size and quality, degree of insulation) and the characteristics of studied organisms (host plants and insect phytophages) [70,72-78]. To our knowledge, there is no study published about the impact of spring caterpillars, from EF trees on LF ones in small forest fragments.

Oaks (Quercus spp.) are among the most infested deciduous trees by early spring Lepidoptera in Central Europe $[4,5,79,80]$. From all oak species in this region, Q. cerris is the last one in terms of bud bursts [81] and, compared with other oaks, this delay is approximately two weeks $[61,82]$. The Quercus cerris often grows with EF deciduous woody species in mixed forests and is also frequent in forest fragments $[66,83,84]$.

Quercus cerris and Q. pubescens Willd. are well adapted to moderate drought stress in summer, and due to a climate change, their increasing importance is expected in temperate European forests [85-91] as well as in Central Europe [92].

We studied (1) whether the infestation of mature LF trees by caterpillars can be affected by neighbouring mature $\mathrm{EF}$ ones in the forest interior and at a distance from it-in small mixed tree groups 20-50 m away from the edges, and (2) whether the infestation of young LF trees by caterpillars can be by neighbouring mature EF ones. We focused on early spring leaf-chewing caterpillars belonging to the group of "brumata-viridana complex" [10] on two co-occurring oak species-the LF Turkey oak (Quercus cerris) and the EF pubescent oak (Q. pubescens). The caterpillar assemblages, usually dominated by the well-known pests Operophtera brumata and Tortrix viridana (hence the name "brumata-viridana complex"), 
comprise numerous lepidopteran species occurring first in spring and being synchronised with the bud burst of EF host trees [10].

We suppose that conditions for the development of neonate (first instar) caterpillars on $Q$. cerris are unfavourable due to late bud burst. Consequently, in early spring, the caterpillar abundance on LF Q. cerris would be lower than on EF Q. pubescens. Later, when the young leaves of $Q$. cerris unfold, caterpillars can switch their hosts to $Q$. cerris trees and profit from the food with higher nutritional quality occurring on this oak species [61]. The probability of $Q$. cerris being infected by caterpillars from $Q$. pubescens would be the highest in the case of trees in close neighbourhood belonging to both oak species $[63,93]$. We assume, therefore, that the caterpillar abundance on mature LF Q. cerris in a closed-canopy forest surrounded by EF Q. pubescens will be higher than the one on LF Q. cerris located out of the forest-in small mixed tree groups and solitary trees. Similarly, caterpillar assemblages on young LF (low) Q. cerris growing under the crowns of mature EF Q. pubescens are expected to be enriched by caterpillars from those mature crowns, unlike the young trees in open space [94]. Thus, mature and young LF trees that are more isolated from EF ones should be less infested by caterpillars.

Our study is clarifying one little-known aspect of a fine-scale mechanism leading locally to the tree diversity effects on herbivory cf. [48,59,74].

\section{Materials and Methods}

\subsection{Studied Area}

The research was carried out in Krupinská planina plateau (Southern Slovakia; $48^{\circ} 10^{\prime} 0.19^{\prime \prime} \mathrm{N}, 18^{\circ} 59^{\prime} 46.08^{\prime \prime} \mathrm{E}$ ) in the southern part of the Western Carpathians Mts, at altitudes between $265 \mathrm{~m}$ and $330 \mathrm{~m}$ a.s.l. The study area belongs to a warm region with mean annual air temperatures $8-9{ }^{\circ} \mathrm{C}$ and mean annual precipitations $600-700 \mathrm{~mm}$ [95]. It is covered with xeric and thermophilous vegetation consisting of an oak forest and a forest-steppe. The share of Quercus pubescens in the forest was accounting for about two thirds of trees, and that of $Q$. cerris about one third. There are other tree species much less frequent and less abundant (up to $2 \%$ ), such as Acer campestre L., A. tataricum L., Tilia spp., Sorbus torminalis (L.) Crantz., Crataegus spp., Carpinus betulus L., Pyrus spp. and Ulmus spp. The average height of mature oaks is $8-12 \mathrm{~m}$ and their age is about 70 years. Young trees and saplings are scattered in the forest understory. The adjacent forest-steppe constitutes a grassland with small tree patches and groups, and solitary trees. Like in the forest, EF Q. pubescens and LF Q. cerris trees are the most frequent here. Several shrub species such as Rosa spp., Crataegus spp., Ligustrum vulgare L. and Prunus spinosa L. also grow in tree patches. The study area was approximately 100 ha (50 ha of forest, 50 ha of forest steppe).

\subsection{Data Collecting}

Caterpillars were obtained from oaks by beating tree branches over a beating tray with $1.0 \mathrm{~m}$ diameter [96], i.e., samples originated from one-metre-long branches or onemetre-long terminal parts of them. Collections were carried out during the non-outbreak period in the first week of May in years 2015 and 2016.

In the first year, caterpillars were collected from mature LF Q. cerris and EF Q. pubescens growing in three types of microhabitats: (1) in a forest; (2) in small mixed tree groups (3-6 trees) composed of both oak species growing in a forest-steppe out of a dense forest; and (3) as solitary (lone) trees also out of it. Regarding the forest, caterpillars were sampled in the forest interior (canopy $80 \%$ ) from mature trees located at a distance of $30-50 \mathrm{~m}$ from the edges, and at least $20 \mathrm{~m}$ from each other.

Every LF Q. cerris tree on which the caterpillars were collected was surrounded by EF $Q$. pubescens with crowns touching those of Q. cerris trees. Also crowns of $Q$. cerris within the mixed groups touched those of $Q$. pubescens trees. Mixed tree groups and solitary trees selected for this study were at a distance of 20-50 m from forest edges, other trees or groups. From each oak species in every microhabitat (i.e., forest, mixed tree groups, and lone trees), 11 samples of caterpillars were obtained, which are $66(2 \times 3 \times 11)$ if taken together. One 
sample represented caterpillars beaten from three branches (up to $3 \mathrm{~m}$ from the ground level), from one mature tree.

In the following year, caterpillars were collected from young LF Q. cerris and EF Q. pubescens (each tree up to $2 \mathrm{~m}$ high) growing in two types of microhabitats: (1) in the forest interior under the crowns of mature $Q$. pubescens at a distance of $30-50 \mathrm{~m}$ from the edges and (2) in open forest glades or edges, as solitary (lone) trees. These solitary young trees were located at $3-5 \mathrm{~m}$ from the crowns of mature trees belonging to any species, including $Q$. pubescens, and at a distance of at least $10 \mathrm{~m}$ from other young trees (Figure 1). From each oak species in every microhabitat (i.e., in a forest under the crowns of $Q$. pubescens, and out of forest in open glades or edges), we collected 15 samples of caterpillar assemblages, which are $60(2 \times 2 \times 15)$ if taken together. One sample represented caterpillars beaten from two branches, from one young tree. Since the mixed groups of young trees composed of LF Q. cerris and EF Q. pubescens altogether were scarce in the study area, we did not include that kind of microhabitat in our research.

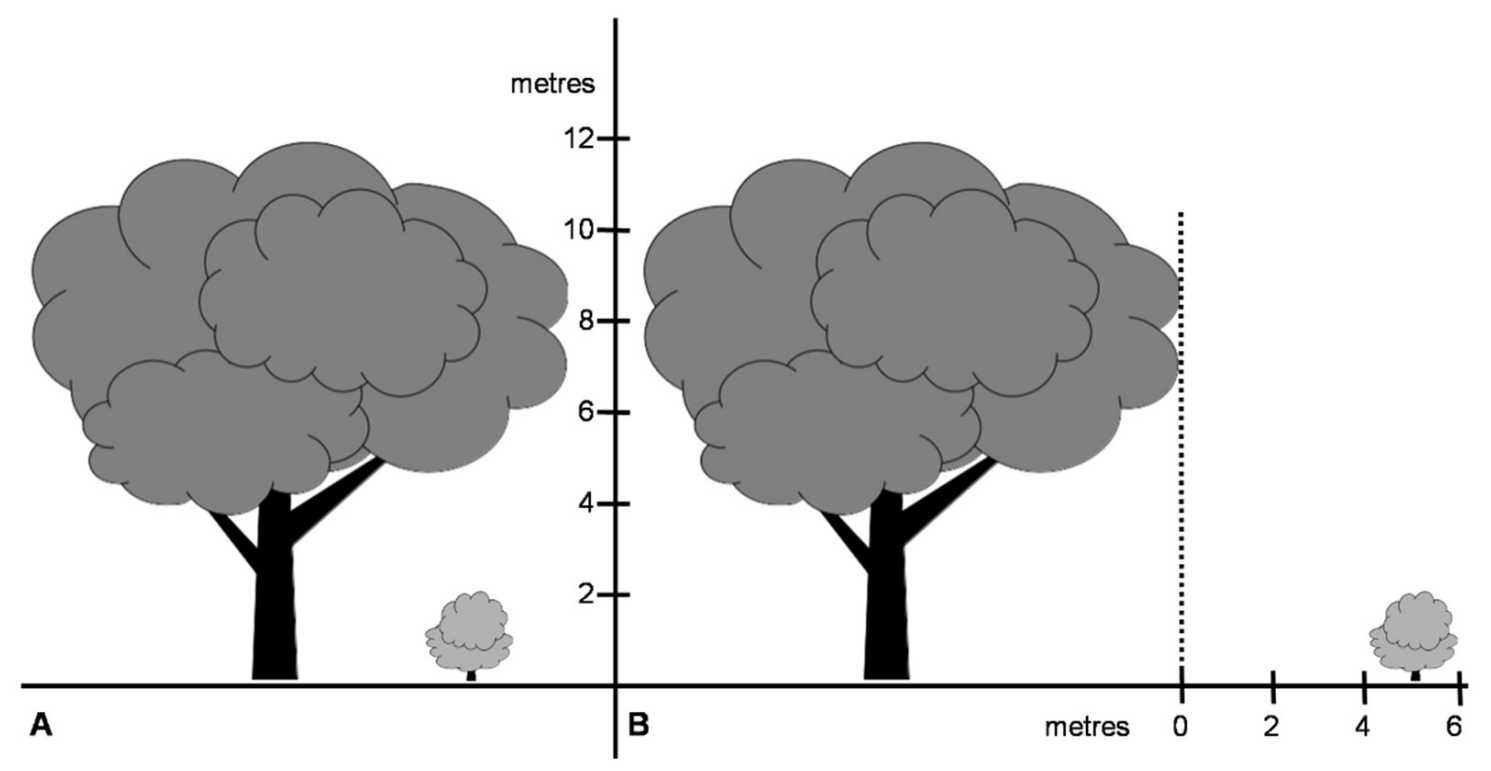

Figure 1. Position of young trees selected to sample caterpillars (mature trees-Quercus pubescens; young trees-Q. cerris or Q. pubescens; (A) - in the forest interior; (B) - in open forest glades or edges [as a solitary tree]).

Caterpillars were preserved in $75 \%$ ethanol and identified in the laboratory by using guides $[2,82,97,98]$. The nomenclature of lepidopteran species follows Pastorális et al. [99]. Two species, Agriopis marginaria (Fabricius, 1776) and A. aurantiaria (Hübner, 1799), which caterpillars are difficult to distinguish from each other according to their external morphology, were considered as a single taxon in the analyses.

\subsection{Data Analyses}

The caterpillar total abundance, and the abundance of A. leucophaearia (Denis and Schiffermüller, 1775) and O. brumata, were statistically compared using analysis of deviance (ANODEV), for mature and young LF Q. cerris and EF Q. pubescens separately. The ANODEV model with a negative binomial error distribution and a log-link function was used to test the effect of tree species and forest structural combinations on the abundance. Permutational multivariate analysis of variance (perMANOVA) was employed for testing the effect of tree species and forest structural combinations on the composition of species assemblages [100]. Data on species abundance were $\log (x+1)$ transformed and the BrayCurtis dissimilarity index [101] was used. The results were presented using the non-metric multidimensional scaling ordination technique (NMDS) [102]. 
The significant level of 0.05 was applied. Statistical analyses and graphical outputs were made in R [103] package boot [104], also using ggplot2 [105], MASS [106], multcomp [107] and vegan [108].

\section{Results}

\subsection{Caterpillars on Mature Trees}

Abundance (Figure 2). Caterpillars on LF Q. cerris were abundant only in the forest interior and this differed significantly from that on $Q$. cerris in mixed tree groups $(\mathrm{z}=-4.280, p<0.001)$ and on lone trees $(\mathrm{z}=-4.796, p<0.001)$. In contrast, caterpillars on $\mathrm{EF} Q$. pubescens were in abundance in all microhabitats without differences between forest and non-forest environment. A difference between $Q$. cerris and Q. pubescens within the forest was considerable but not significant $(z=2.413, p=0.088)$.
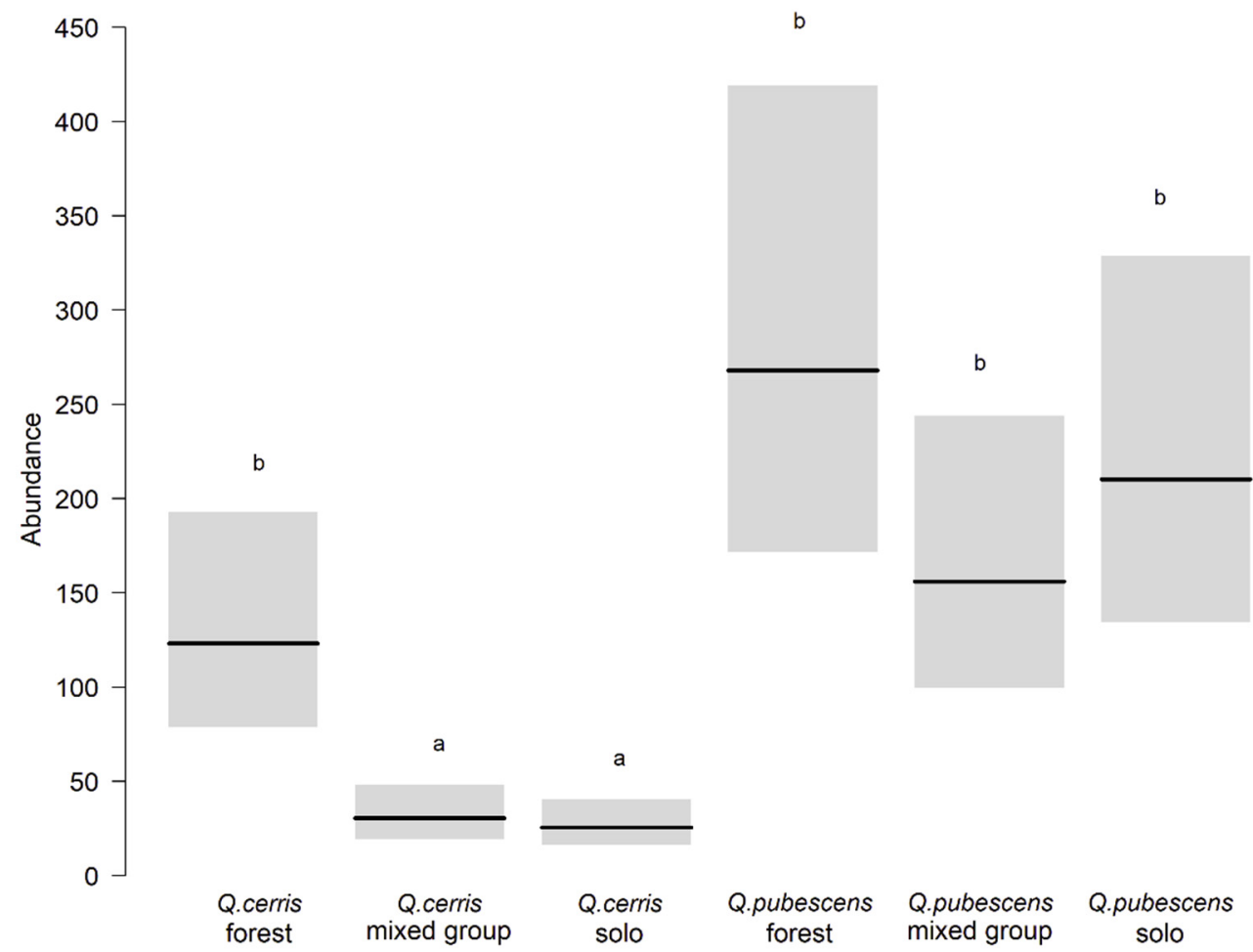

Figure 2. Abundance of caterpillars (number of individuals on three branches, each $1 \mathrm{~m} \mathrm{long}$ ) on mature LF Quercus cerris and EF Q. pubescens located in the forest interior (forest) and out of it, in mixed tree groups composed of Q. cerris and Q. pubescens, and on lone (solo) trees. A horizontal line denotes the mean, and bars the $95 \%$ confidence intervals. Distinct letters above columns indicate a significant difference.

Species composition (Figure 3). Caterpillar assemblages on LF and EF trees did not differ between each other in the forest interior $(\mathrm{F}=2.094, p=0.105)$ but they significantly did in a non-forest environment-in mixed tree groups $(\mathrm{F}=11.258, p<0.001)$ and on lone trees $(\mathrm{F}=12.639, p<0.001)$. Assemblages on $Q$. cerris in microhabitats out of the forest had a similar composition $(\mathrm{F}=0.487, p>0.100)$ but they were different from those in forest (mixed groups: $\mathrm{F}=4.660, p=0.003$; lone trees: $\mathrm{F}=5.836, p<0.001$ ). The same was found for assemblages on $Q$. pubescens (mixed groups vs. lone trees: $\mathrm{F}=2.104, p>0.05$; mixed groups vs. forest: $\mathrm{F}=4.331, p=0.001$; lone trees vs. forest: $\mathrm{F}=4.709, p<0.001$ ). 


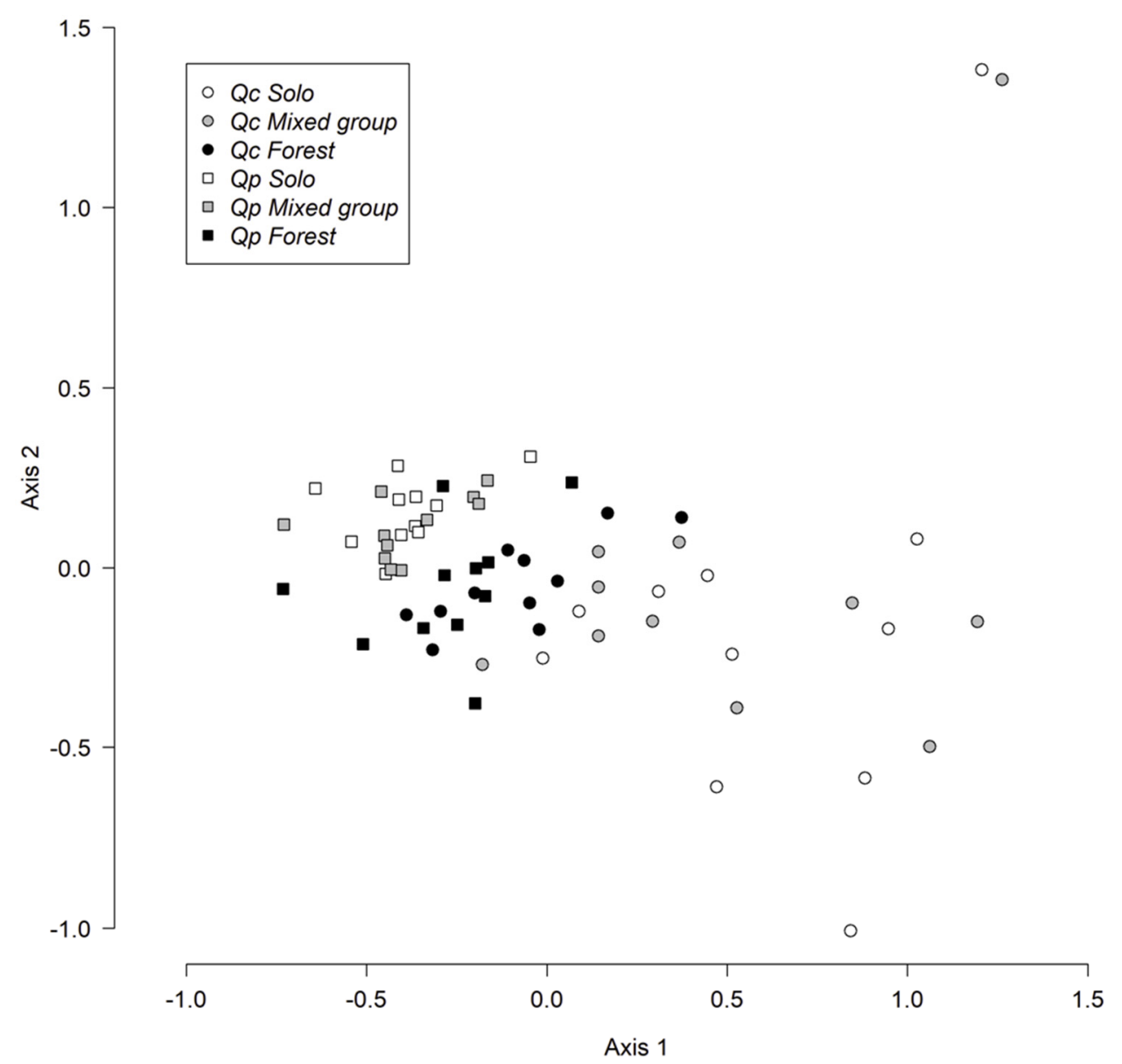

Figure 3. Non-metric multidimensional scaling of caterpillar assemblages on mature LF Quercus cerris and EF Q. pubescens. (Qc-Q.cerris, Qp-Q. pubescens, Solo-lone trees, Mixed group-mixed tree groups composed of $Q$. cerris and $Q$. pubescens, Forest—-trees growing in the forest interior).

Agriopis leucophaearia (Figure 4). This species was predominant in all microhabitats on both oak species (LF Q. cerris-dominance in forest: $87 \%$, in mixed tree groups: $72 \%$, on lone trees: 78\%; EF Q. pubescens-in forest: $91 \%$, in mixed groups: $72 \%$, on lone trees: $69 \%$ ), significantly influencing the abundance of caterpillar assemblages. On Q. pubescens, this moth was abundant in all microhabitats. In contrast, on Q. cerris it was abundant only in the forest interior and much less abundant in mixed tree groups $(\mathrm{z}=-4.111, p<0.001)$ and on lone trees $(\mathrm{z}=-4.342, p<0.001)$.

Operophtera brumata (Figure 5). The second most abundant moth also appeared on the two oak species (LF Q. cerris-dominance in forest: $4 \%$, in mixed tree groups: $2 \%$, on lone trees: $2 \%$; EF Q. pubescens-in forest: 3\%, in mixed groups: $11 \%$, on lone trees: $19 \%$ ). Its caterpillars on both oaks were similarly abundant in the forest interior $(\mathrm{z}=1.577, p>0.100)$. On $Q$. cerris, they were significantly less in abundance out of it-in mixed tree groups $(\mathrm{z}=-3.708, p<0.001)$ and on lone trees $(\mathrm{z}=-4.072, p<0.001)$. In contrast, on Q. pubescens, they were more abundant in mixed tree groups $(z=2.621, p=0.034)$ and especially on lone trees $(\mathrm{z}=5.258, p<0.001)$ when compared with the forest interior.

\subsection{Caterpillars on Young Trees}

Abundance (Figure 6). Caterpillars were abundant on both oak species growing under mature EF Q. pubescens in the forest interior and did not differ significantly between each other $(\mathrm{z}=1.275, p>0.100)$. Those on LF $Q$. cerris were less abundant on lone trees than in the forest interior $(\mathrm{z}=-3.520, p=0.002)$ while caterpillars on EF $Q$. pubescens were also in abundance on lone trees, and this did not differ from that within the forest $(z=-1.296, p>0.100)$. 

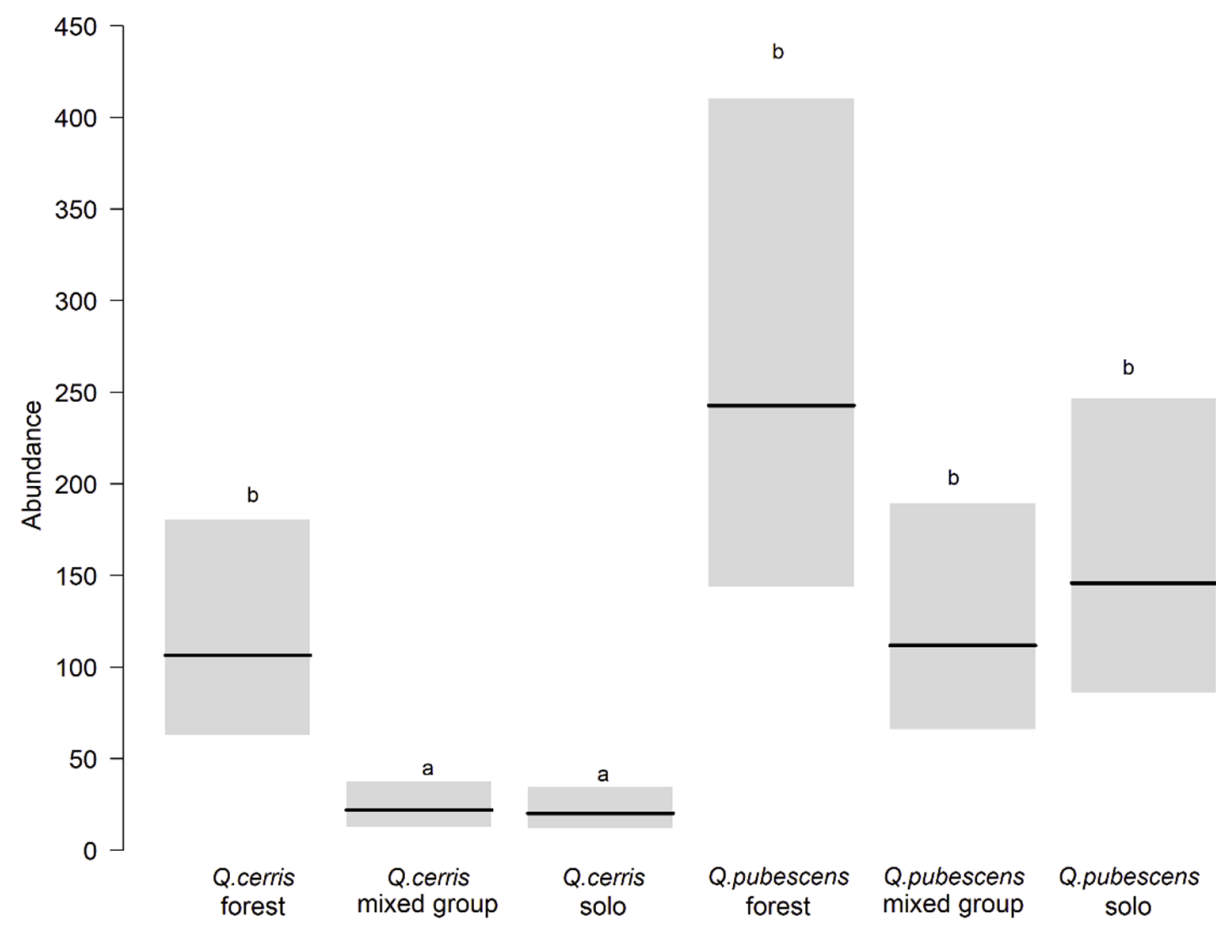

Figure 4. Abundance of Agriopis leucophaearia caterpillars (number of individuals on three branches, each $1 \mathrm{~m}$ long) on mature LF Quercus cerris and EF Q. pubescens located in the forest interior (forest) and out of it, in mixed tree groups composed of $Q$. cerris and Q. pubescens, and on lone (solo) trees. A horizontal line denotes the mean, and bars the $95 \%$ confidence intervals. Distinct letters above columns indicate a significant difference.

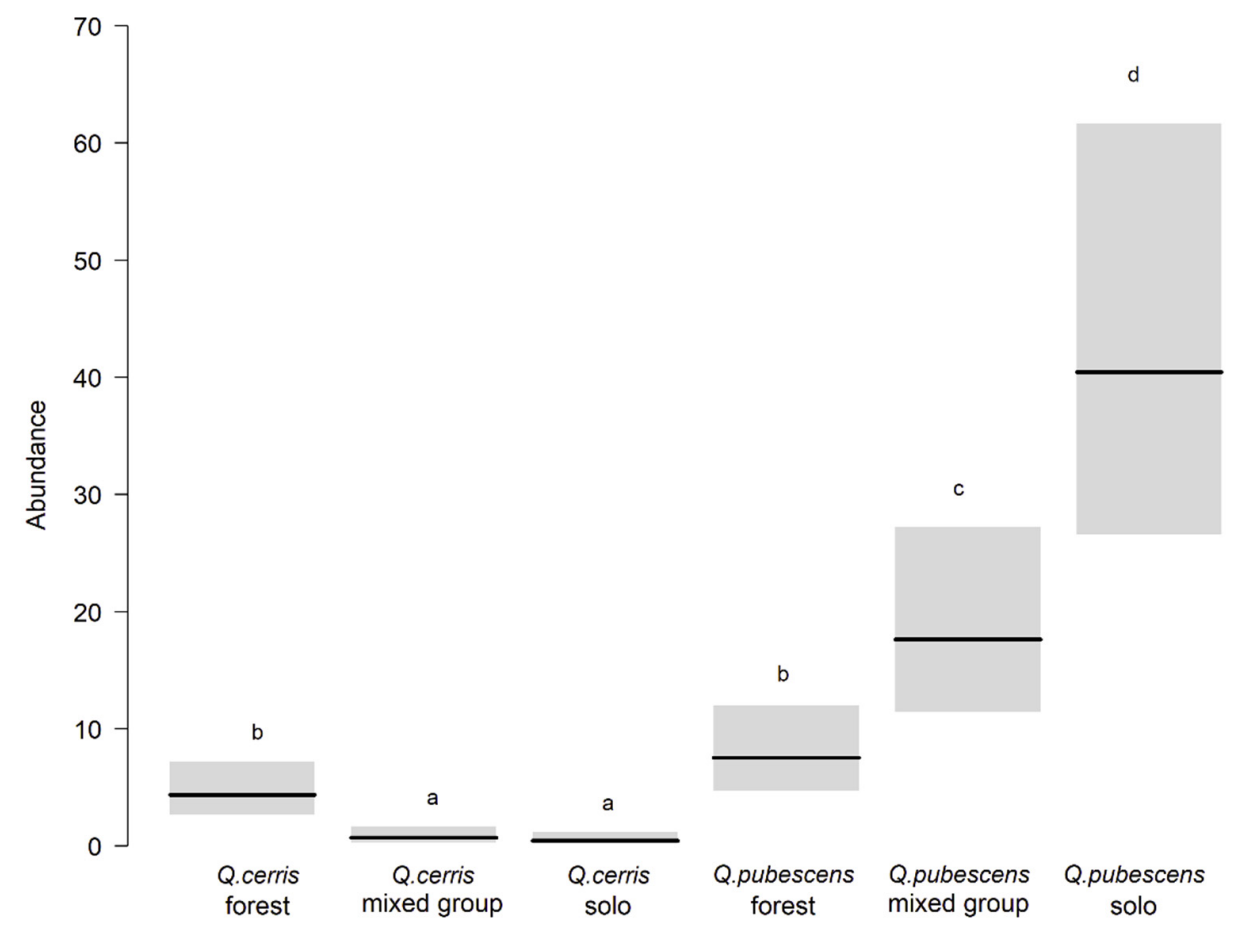

Figure 5. Abundance of Operophtera brumata caterpillars (number of individuals on three branches, each $1 \mathrm{~m}$ long) on mature LF Quercus cerris and EF Q. pubescens located in the forest interior (forest), and out of it, in mixed tree groups composed of $Q$. cerris and Q. pubescens, and on lone (solo) trees. A horizontal line denotes the mean, and bars the $95 \%$ confidence intervals. Distinct letters above columns indicate a significant difference. 

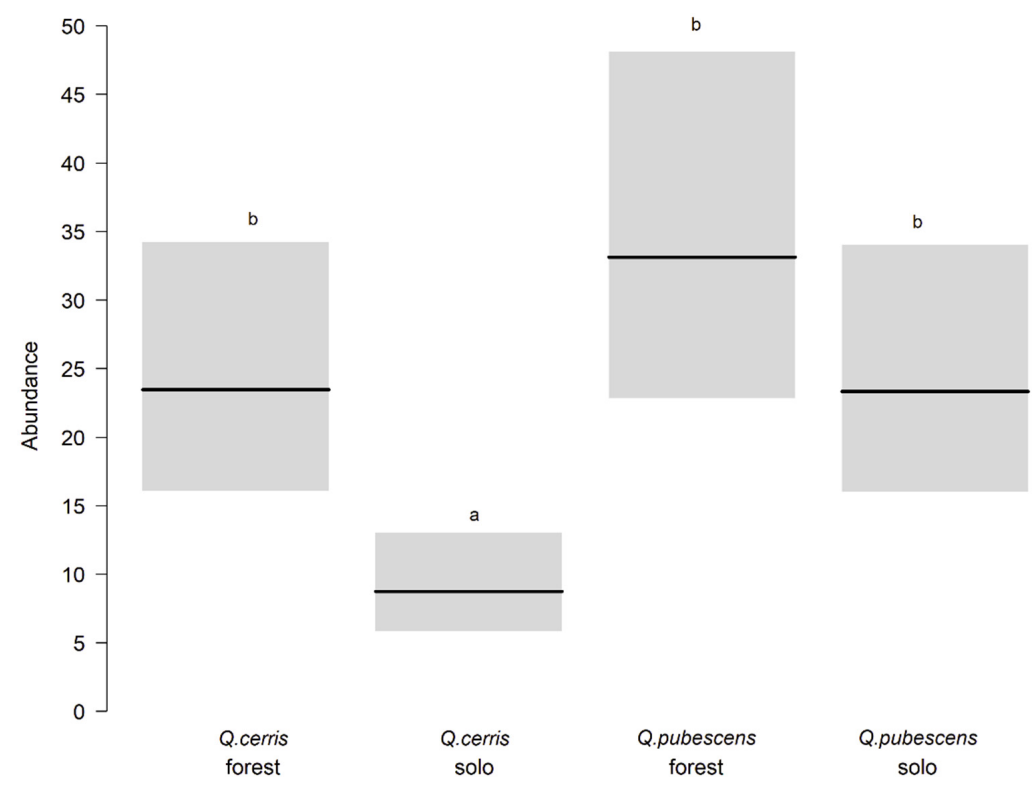

Figure 6. Abundance of caterpillars (number of individuals on two branches, each $1 \mathrm{~m} \mathrm{long}$ ) on young LF Quercus cerris and EF Q. pubescens located in the forest interior and on lone (solo) trees in open forest glades or edges. A horizontal line denotes the mean, and bars the $95 \%$ confidence intervals. Distinct letters above columns indicate a significant difference.

Species composition (Figure 7). Caterpillar assemblages on LF Q. cerris and EF Q. pubescens did not differ between each other in the forest interior $(\mathrm{F}=2.586, p=0.082)$ but they significantly did in a non-forest environment, i.e., on lone trees $(\mathrm{F}=3.100, p=0.014)$. In the case of Q. cerris, assemblages on lone trees were different from those within the forest $(\mathrm{F}=3.136$, $p=0.014$ ) while for $Q$. pubescens, they were similar on lone trees and in the forest interior $(\mathrm{F}=0.778, p>0.1)$.

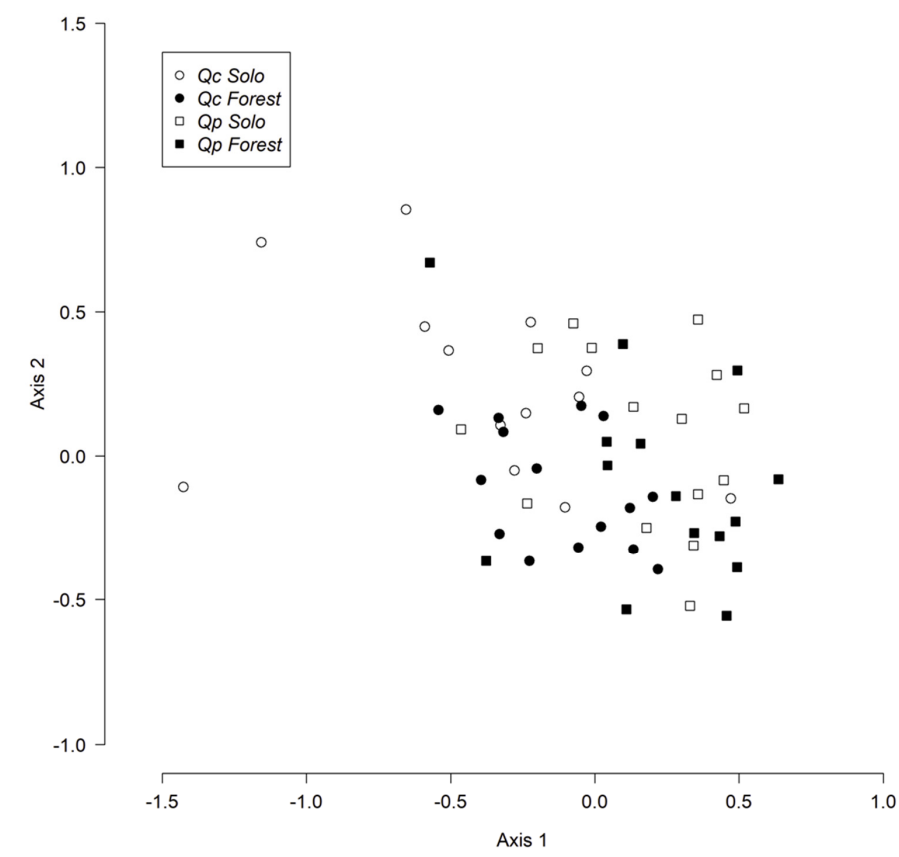

Figure 7. Non-metric multidimensional scaling of caterpillar assemblages on young LF Quercus cerris and EF Q. pubescens. (Qc-Q. cerris, Qp-Q. pubescens, Solo-lone trees growing in open forest glades or edges out of the crowns of mature $Q$. pubescens, Forest-trees in the forest interior under the crowns of mature Q. pubescens). 
Agriopis leucophaearia (Figure 8). It was a predominant species also on young LF Q. cerris (dominance in the forest interior: $83 \%$, lone trees: $77 \%$ ) and EF Q. pubescens (within the forest: $70 \%$, lone trees: $67 \%$ ). In the forest interior, there was a non-significant difference between caterpillar abundances on $Q$. cerris and $Q$. pubescens $(z=0.559, p>0.100)$. On lone trees, their abundance on $Q$. cerris was significantly lower than that in the forest interior $(\mathrm{z}=-3.390, p=0.005)$ while on $Q$. pubescens it was relatively high, and the difference between abundances, in both microhabitats, was not significant $(z=-1.309, p>0.100)$.

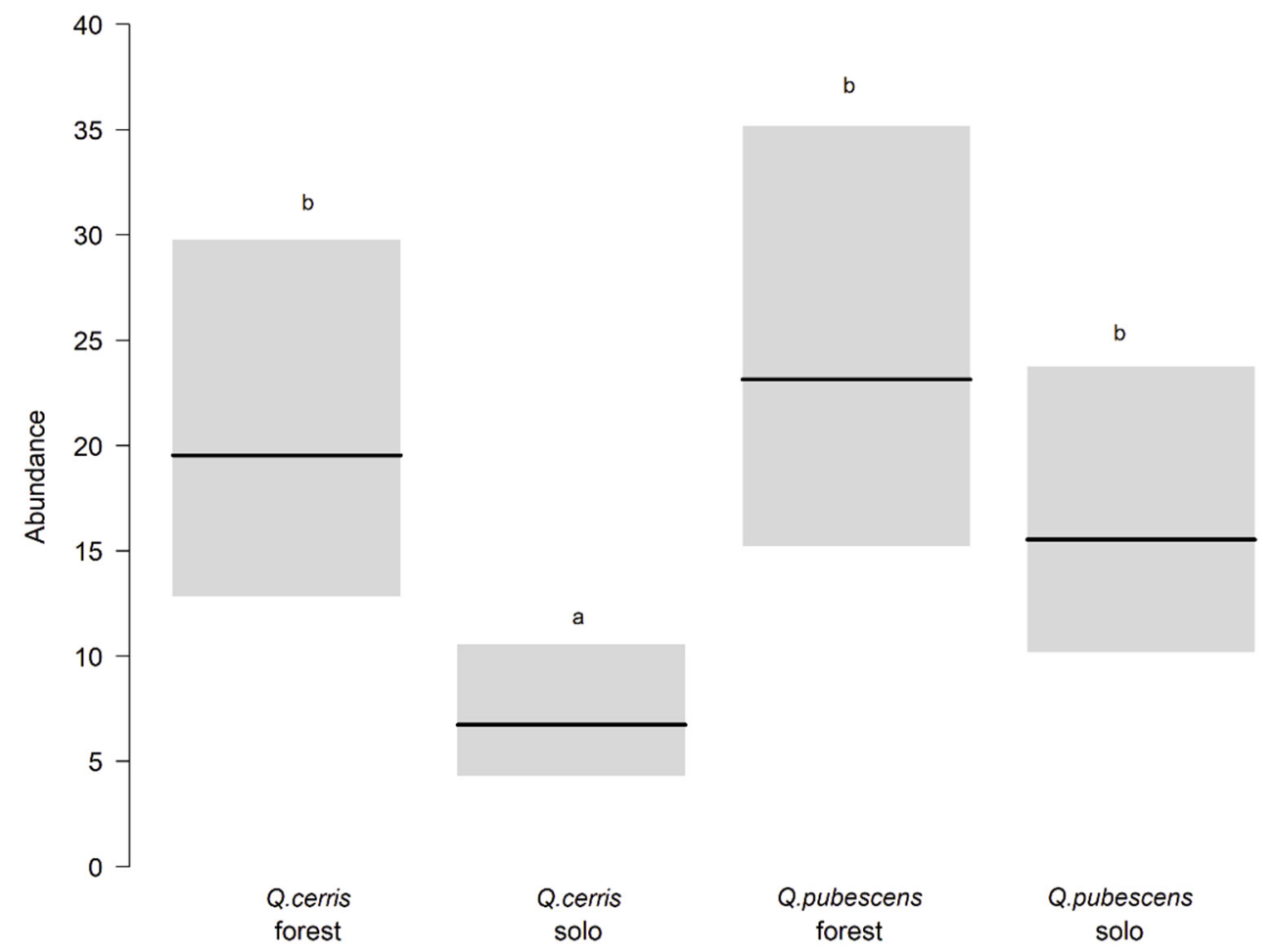

Figure 8. Abundance of Agriopis leucophaearia caterpillars (number of individuals on two branches, each $1 \mathrm{~m}$ long) on young LF Quercus cerris and EF Q. pubescens located in the forest interior and on lone (solo) trees in open forest glades or edges. A horizontal line denotes the mean, and bars the $95 \%$ confidence intervals. Distinct letters above columns indicate a significant difference.

\section{Discussion}

Our research has revealed that caterpillar assemblages on LF Q. cerris and EF Q. pubescens were similar in the closed-canopy mixed forest composed of both LF and EF trees and different on those growing out of it. In the forest, the caterpillar abundance on mature LF trees almost reached that on mature EF trees (insignificant difference). In microhabitats out of the forest-on small mixed tree groups composed of both species and on lone trees, caterpillars on LF oaks were significantly less abundant than on EF ones. Moreover, the species composition of their assemblages on LF Q. cerris and EF Q. pubescens was similar in the forest interior but different in microhabitats out of it. It suggests an increased infestation by caterpillars (measured as a caterpillar abundance) of LF trees surrounded by EF ones in forest (associational susceptibility). This latter effect could be the result of a spill-over where herbivores move from neighbouring primary host trees (Q. pubescens) onto secondary host trees (Q. cerris) at the centre.

Early spring Lepidoptera, as recorded, can develop on the leaves of both studied oak species $[5,9,10,79,109,110]$, but caterpillars in Central Europe hatch synchronously with opening buds of EF Q. pubescens [5]. Previous studies have reported low abundances of caterpillars on Q. cerris $[9,10,31,111]$ and J. Liška, pers. comm. These low abundances observed without taking into account the possible effect of neighbouring trees may reflect environmental conditions which are harsher for first-instar caterpillars on this LF 
oak species than on other oaks. Our results have also confirmed the significantly lower abundance of caterpillars on LF Q. cerris than on EF Q. pubescens for solitary growing trees.

We studied the associational effect of neighbouring trees on spring caterpillar assemblages feeding on two oak species. The abundance and composition of these assemblages were mostly determined by two dominant moth species, A. leucophaearia and O. brumata, occurring frequently and in abundance on Central European oak species [2-5,9-12]. As for other tree species and their caterpillar assemblages, further research is needed.

Females of many early spring Lepidoptera oviposit at times different from those over which their offspring develops in. It means that these females do not experience environmental conditions their caterpillars are going to live next spring. Thus, there is a poor chance for them to select the best food resources for their future offspring [112]. Non-selective oviposition has been documented in common geometrids O. brumata and Epirrita autumnata (Borkhausen, 1794) [36,113,114]. Also, Tiberi et al. [115] recorded a similar number regarding eggs of Tortrix viridana on two oak species, Q. cerris and Q. pubescens. The oviposition of remaining species from the "brumata-viridana complex" has not been studied yet, but it is highly probable that the females place their eggs on both oaks.

The majority of caterpillars that hatched on LF oaks need to find new feeding places. Only some neonates among them can stay on this host tree-either those hatching later or those which are lucky to do it on a branch or tree with unusually early flushing buds. Previous studies suggest that small caterpillars leave relatively often their primary places to feed $[18,31,32,113,116,117]$, however, inclination to disperse is a species-specific trait [14]. Baby caterpillars that were dispersing through ballooning can reach neighbouring or closegrowing trees quite easily [31,113], and can increase caterpillar abundance on EF trees. The question of an extent to which neonate caterpillars being dispersed from LF $Q$. cerris affect neighbouring EF Q. pubescens trees remains still unknown. Similarly, the knowledge of dispersing late-instar caterpillars between trees is insufficient; this phenomenon has been most studied marginally, and only in some species so far $[60,61,93,118,119]$.

There are plenty of abiotic and biotic stimuli inducing caterpillars to leave their feeding places (e.g., low quality or lack of food, a contact with a predator or parasitoid, physical stimuli caused by weather conditions, etc.) $[4,60,61,94,120-126]$. Many caterpillars can be seen as they climb tree trunks to get into crowns after rainstorms or strong winds (pers. observations of authors). Dispersing larvae have a better chance to survive when finding suitable feeding places near their primary host trees. It is assumed that the impact of those caterpillars on other trees is predominantly local $[63,93,127,128]$.

The presence of EF Q. pubescens in isolated small mixed tree groups seems to be insufficient to increase considerably the caterpillar abundance or affect the composition of their assemblages on LF Q. cerris. Dispersal of neonate caterpillars (at least some species) may easily overcome distances between microhabitats we have studied (20-50 m) ([30-33] and references therein). However, ballooning is of little importance for the redistribution of caterpillars onto $Q$. cerris trees as their buds are still mostly closed at a time when they are hatching. Older caterpillars have limited ability to spill over, from EF primary host to neighbouring LF trees growing in small isolated groups. Hanging on silk threads or falling on the ground in such a microhabitat, they may easily miss neighbouring trees, and get lost in open space. Similarly, we suppose that solitary growing trees are highly improbable to be reached by older caterpillars from a forest or other trees being several tens of metres away. Consequently, in microhabitats out of forest, adults that originated from caterpillars living on LF Q. cerris are less abundant than those on EF Q. pubescens. Thus, the abundance of females laying eggs on $Q$. cerris is also lower and only a small part of offspring (i.e., caterpillars having hatched later) complete its development on trees belonging to this LF oak species. To summarise it, the small number of eggs and the few possibilities to enrich their assemblages from more infested EF Q. pubescens contribute together in low caterpillar abundances on LF Q. cerris trees.

Very low caterpillar abundance on LF Q. cerris in small fragments distant several tens of metres from a continuous forest suggests that no specialised lepidopteran population is 
genetically adapted on these trees unlike some known cases $[18,129,130]$. In mixed forests where moth adults and caterpillars move between trees, interbreeding of individuals that develop on different plants occurs. Both sexes or at least males, and some neonate caterpillars can overcome short distances between a forest and its fragments $[31,131,132]$ is what inhibits a genetically determined specialisation on trees with specific phenology [19].

The caterpillar abundance on mature EF Q. pubescens in small forest fragments, i.e., mixed tree groups and solitary trees, almost reached that in the forest interior but the composition of their assemblages in these microhabitats differed from those in forest. On oaks, a small or positive effect of forest fragmentation on herbivory has been recorded e.g., $[47,77]$. Caterpillars living on solitary trees and those in small groups out of forest are influenced by distinct conditions present within the forest [133-136] as well as the different quality of leaves, as their food plays an important role when compared with these in the forest interior [137-140]. The above-mentioned conditions together with the preference of certain habitats varying among species [5,141-143] determine the assemblages of herbivores.

Agriopis leucophaearia, the most dominant species recorded in caterpillar assemblages, on mature EF Q. pubescens, was in abundance, almost as in microhabitats out of forest as within it (differences were not significant), thus, it follows that the moth does not prefer any of the specific environments given. This species was abundant as well on Q. pubescens in open-canopy forest [10]. In contrast, another dominant species, O. brumata, appeared on Q. pubescens in higher abundance in microhabitats out of forest than in a continuous forest. It could be caused by its different habitat preference, since this moth is also abundant in fruit orchards [93,113,114,144-147], parks and urban alleys of trees [142,148,149] where the latter or shrubs do not grow close to each other. Van Dongen et al. [68] and van Dongen \& Scott [72] studied O. brumata in patches, larger and more isolated in comparison with those in our research, and they recorded the negative effect of patch isolation on this moth.

On mature LF Q. cerris, caterpillar assemblages on small tree groups and on solitary trees differed from those in the forest interior. Although A. leucophaearia and O. brumata were dominant on these oaks in the studied small forest fragments, being very low abundant suggest that $Q$. cerris is not a suitable host for them in such microhabitats. Other lepidopteran species occurred there in low abundance, too.

We have also recorded associational susceptibility in young LF Q. cerris growing in close vicinity (i.e., right under the crowns) of mature $\mathrm{EF}$ Q. pubescens within the forest. These young LF trees were infested by caterpillars more significantly than young ones in open space-in open forest glades or edges. In forest, caterpillar assemblages on young LF and EF trees were similar. These results suggest that a close distance between young LF trees and mature EF ones is crucial because dispersing caterpillars reach rather closely trees in growth. Saplings and other plants in the forest understory are known to be infested by caterpillars that descend on silk threads or fall from the forest canopy (e.g., in searching for food) $[5,39,94,121,141]$. The frequency of the movements made by caterpillars between forest strata has not been studied so far. The reported abundance of the dominant species A. leucophaearia suggests that young LF $Q$. cerris growing out of the close range from mature $\mathrm{EF} Q$. pubescens be less suitable than trees in forest under the crowns of mature $Q$. pubescens, for the larval development of this moth. We did not statistically analyse other lepidopteran species due to their low abundances.

Effects of associational susceptibility on secondary host trees are known mainly during outbreaks when previously unsuitable or suboptimal hosts were also infested $[4,7,45,60,150]$. We have recorded positive associational effects of EF trees on LF ones at reduced (nonoutbreak) herbivore abundance. Our results show that the effect of EF trees on LF ones is manifested only in close vicinity of trees in forest. So, tree density and forest fragmentation can modify the strength of the associational effect trees with different phenology have. The high caterpillar abundance on LF Q. cerris in closed-canopy forest seems to be the result of the tree-to-tree movement of older larvae and probably of high numbers of moth eggs laid on Q. cerris (comparable with those on Q. pubescens). Also, other studies describing the 
effects of associational susceptibility on woody plants are linked to forests or dense stands of trees $[4,7,39,45,60,61,94,150,151]$. The importance of the close vicinity around early- and late-flushing trees for associational effects was indicated by the results of our previous research. In a sparse forest (an open-canopy forest) dominated by both studied oak species, mature and young LF $Q$. cerris were significantly less infested by early spring caterpillars than EF Q. pubescens [10].

The composition of caterpillar assemblages on both oak species was similar in forest but differed in microhabitats out of it. It suggests that the associational effect of EF oaks on LF ones is related to many lepidopteran species. The most abundant moth, A. leucophaearia, can feed on broad-leaved tree species preferring oaks $[10,80,152]$. The second in abundance, $O$. brumata, is a typical generalist $[31,80,82,114]$. The studied type of associational susceptibility can develop when both plants at the centre and in the surroundings are palatable for these herbivores [50]. In case of phylogenetically related and palatable hosts (in our study, Q. cerris and Q. pubescens), herbivores can have a broad $[4,51,150]$ as well as a narrow diet breadth $[45,60]$.

Except for well-known species of early spring Lepidoptera that are considered pests, A. leucophaearia should also be added to the list of forest pests, since it was abundant in our study area and other Central European regions, too [10,12,82,153,154].

The method used (branch beating) is appropriate and advantageous for collecting externally feeding leaf-chewing caterpillars of early spring Lepidoptera [155]. In case of mature trees, these were only obtained from the lower part of tree crowns (up to $3 \mathrm{~m}$ from the ground) but for the comparison of caterpillar assemblages between two oak species it was sufficient. All comparable microhabitats in this study were located in the same biogeographical area and landscape structure. In each microhabitat examined, the same (or very similar) abiotic (e.g., climatic) and biotic (e.g., predators and parasitoids) factors acted on caterpillars on both oak species (Q. cerris and Q. pubescens). There were differences only between conditions associated with host species (different phenology and food quality). This enabled us to acquire new knowledge on fine-scale mechanisms leading to the increased caterpillar infestation of LF trees in the immediate vicinity of EF ones.

Our results suggest that EF trees influence the surrounded LF ones regularly (every season). Such influence can be modified by other factors. For example, the content of chemical substances in oak leaves is species-specific [156,157], so we cannot rule out differences in the palatability of Q. cerris and Q. pubescens leaves for early spring caterpillars. Severe defoliation can induce resistance against leaf-chewing insects in the following year [158]. On the other hand, trees which usually few caterpillars feed on, i.e., those with low resistance (such as $Q$. cerris) could be sporadically heavily infested by herbivore insects, for example by Lymantria dispar L. [159]. In addition, global warming can disrupt the synchrony of EF oak and spring Lepidoptera phenology [160] and affect the abundance of caterpillars on trees. Associational effects of EF trees on LF ones can be connected with forest health deterioration, as weakened trees are often infested by various insect pests [5]. Moreover, young leaves produced by damaged oaks are often damaged by oak powdery mildew [161]. Further studies should address these issues in detail.

Our findings are important for silvicultural practices. The establishment of mixed forest stands with distinct tree species or cultivars using a different time for bursting can increase the susceptibility of certain trees to the attack of herbivores. These trees can be considered resistant if growing in monocultures or with other species with similar phenology. For example, in monocultures of LF Q. cerris in Central Europe, Lepidoptera within the "brumata-viridana complex" occur in small abundances (J. Liška, pers. comm.). The seedlings of resistant species or cultivars planted under mature trees with different phenology may also be attacked by herbivores more strongly than when they are in open space. Before the establishment of any forest or park stand, we recommend, therefore, to take into account traits of trees and the local fauna of potential pests. 


\begin{abstract}
Author Contributions: Conceptualization, L.S., P.Z. and J.K.; methodology, L.S., P.Z. and J.K.; software, M.P.; validation, L.S., M.P. and J.K.; formal analysis, L.S., M.P. and M.S.; investigation, L.S., P.Z., M.P., M.S. and J.K.; resources, L.S. and J.K.; data curation, L.S.; writing-original draft preparation, L.S. and J.K.; writing-review and editing, L.S., P.Z., M.P., M.S. and J.K.; visualization, L.S. and M.P.; supervision, J.K.; project administration, J.K. and P.Z.; and funding acquisition, J.K. and P.Z. All authors have read and agreed to the published version of the manuscript.
\end{abstract}

Funding: This research was funded by the Slovak Grant Agency for Science (VEGA) via grant no. VEGA 2/0032/19 as well as by the Slovak Research and Development Agency (APVV) via grant no. APVV-19-0119.

Acknowledgments: We thank Dominique Fournier for linguistic improvements and Milan Mikuš for technical assistance with data collecting.

Conflicts of Interest: The authors declare no conflict of interest.

\title{
References
}

1. Elton, C.S. The forest canopy: Herbivores. In The Pattern of Animal Communities, 1st ed.; Springer: Dordrecht, The Netherlands, 1966; pp. 190-209. [CrossRef]

2. Patočka, J. Die Raupen und Puppen der Eichenschmetterlinge Mitteleuropas, 1st ed.; Paul Parey: Hamburg/Berlin, Germany, $1980 ;$ p. 188.

3. Csóka, G. Oak Defoliating Insects in Hungary. In Proceedings of the Population Dynamics, Impacts, and Integrated Management of Forest Defoliating Insects, Banská Štiavnica, Slovakia, 18-23 August 1996; McManus, M.L., Liebhold, A.M., Eds.; USDA Forest Service General Technical Report NE-247. USDA: Madison, WI, USA, 1998; pp. 334-335.

4. Topp, W.; Kulfan, J.; Mergel, S.; Zach, P. Massenvermehrung von phyllophagen Schmetterlingen in Laubwäldern des Rheinlands. Anz. Schädlingskd. Pfl. Umwelt. 1998, 71, 88-93. [CrossRef]

5. Patočka, J.; Krištín, A.; Kulfan, J.; Zach, P. Die Eichenschädlinge und Ihre Feinde, 1st ed.; Institut für Waldökologie der Slowakischen Akademie der Wissenschaften: Zvolen, Slovakia, 1999; p. 396.

6. Ruohomäki, K.; Tanhuanpää, M.; Ayres, M.P.; Kaitaniemi, P.; Tammaru, T.; Haukioja, E. Causes of cyclicity of Epirrita autumnata (Lepidoptera, Geometridae): Grandiose theory and tedious practice. Popul. Ecol. 2000, 42, 211-223. [CrossRef]

7. Wesołowski, T.; Rowiński, P. Late leaf development in pedunculate oak (Quercus robur): An antiherbivore defence? Scand. J. For. Res. 2008, 23, 386-394. [CrossRef]

8. Glavendekić, M.M.; Medarević, M.J. Insect defoliators and their influence on oak forests in the Djerdap National Park, Serbia. Arch. Biol. Sci. 2010, 62, 1137-1141. [CrossRef]

9. Kulfan, M. Structure of lepidopterocenoses on oaks Quercus dalechampii and Q. cerris in Central Europe and estimation of the most important species. Munis Entmol. Zool. 2012, 7, 732-741.

10. Kulfan, J.; Sarvašová, L.; Parák, M.; Dzurenko, M.; Zach, P. Can late flushing trees avoid attack by moth larvae in temperate forests? Plant Protect. Sci. 2018, 54, 272-283. [CrossRef]

11. Zúbrik, M.; Pilarska, D.; Kulfan, J.; Barta, M.; Hajek, A.E.; Bittner, T.D.; Hirka, A. Phytophagous larvae occurring in Central and Southeastern European oak forests as a potential host of Entomophaga maimaiga (Entomophthorales: Entomophthoraceae)—A field study. J. Invertebr. Pathol. 2018, 155, 52-54. [CrossRef]

12. Sarvašová, L.; Kulfan, J.; Saniga, M.; Zúbrik, M.; Zach, P. Winter geometrid moths in oak forests: Is monitoring a single species reliable to predict defoliation risk? Forests 2020, 11, 288. [CrossRef]

13. Du Merle, P. Phenological resistance of oaks to the green leafroller, Tortrix viridana (Lepidoptera: Tortricidae). In Mechanisms of Woody Plant Defences against Insects, 1st ed.; Springer: Berlin/Heidelberg, Germany; New York, NY, USA, 1988; pp. 215-226. [CrossRef]

14. Hunter, M.D. Differential susceptibility to variable plant phenology and its role in competition between two insect herbivores on oak. Ecol. Entomol. 1990, 15, 401-408. [CrossRef]

15. Hunter, M.D. A variable insect-plant interaction: The relationship between tree budburst phenology and population levels of insect herbivores among trees. Ecol. Entomol. 1992, 17, 91-95. [CrossRef]

16. Van Dongen, S.; Backeljau, T.; Matthysen, E.; Dhondt, A.A. Synchronization of hatching date with budburst of individual host trees (Quercus robur) in the winter moth (Operophtera brumata) and its fitness consequences. J. Anim. Ecol. 1997, 66, 113-121. [CrossRef]

17. Hunter, A.F.; Elkinton, J.S. Effects of synchrony with host plant on populations of a spring feeding Lepidopteran. Ecology 2000, 81, 1248-1261. [CrossRef]

18. Tikkanen, O.-P.; Lyytikäinen-Saarenmaa, P. Adaptation of a generalist moth, Operophtera brumata, to variable budburst phenology of host plants. Entomol. Exp. Appl. 2002, 103, 123-133. [CrossRef]

19. Tikkanen, O.-P.; Julkunen-Tiitto, R. Phenological variation as protection against defoliating insects: The case of Quercus robur and Operophtera brumata. Oecologia 2003, 136, 244-251. [CrossRef]

20. Van Asch, M.; Visser, M.E. Phenology of forest caterpillars and their host trees: The importance of synchrony. Annu. Rev. Entomol. 2007, 52, 37-55. [CrossRef] [PubMed] 
21. Fuentealba, A.; Pureswaran, D.; Bauce, É.; Despland, E. How does synchrony with host plant affect the performance of an outbreaking insect defoliator? Oecologia 2017, 184, 847-857. [CrossRef]

22. Keena, M.A.; Shi, J. Effects of temperature on first instar Lymantria (Lepidoptera: Erebidae) survival and development with and without food. Environ. Entomol. 2019, 48, 655-666. [CrossRef]

23. Feeny, P. Seasonal changes in oak leaf tannins and nutrients as a cause of spring feeding by winter moth caterpillars. Ecology 1970, 51, 565-581. [CrossRef]

24. Schultz, J.C.; Nothnagle, P.J.; Baldwin, I.T. Seasonal and individual variation in leaf quality of two northern hardwoods tree species. Am. J. Bot. 1982, 69, 753-759. [CrossRef]

25. Raupp, M.J.; Werren, J.H.; Sadof, C.S. Effects of short-term phenological changes in leaf suitability on the survivorship, growth and development of gypsy moth (Lepidoptera: Lymantriidae) larvae. Environ. Entomol. 1988, 17, 316-319. [CrossRef]

26. Hunter, A.F.; Lechowicz, M.J. Foliage quality changes during canopy development of some northern hardwood trees. Oecologia 1992, 89, 316-323. [CrossRef] [PubMed]

27. Jones, B.C.; Despland, E. Effects of synchronization with host plant phenology occur in the larval development of a spring folivore. Can. J. Zool. 2006, 84, 628-633. [CrossRef]

28. Martemyanov, V.V.; Pavlushin, S.V.; Dubovskiy, I.M.; Yushkova, Y.V.; Morosov, S.V.; Chernyak, E.I.; Efimov, V.M.; Ruuhola, T.; Glupov, V.V. Asynchrony between host plant and insects-defoliator within a tritrophic system: The role of herbivore innate immunity. PLoS ONE 2015, 10, e0130988. [CrossRef] [PubMed]

29. Barbehenn, R.V.; Kapila, M.; Kileen, S.; Nusbaum, C.P. Acquiring nutrients from tree leaves: Effects of leaf maturity and development type on a generalist caterpillar. Oecologia 2017, 184, 59-73. [CrossRef] [PubMed]

30. Brown, C.E. The life history of the Bruce spanworm, Opheroptera bruceata (Hulst), (Lepidoptera: Geometridae). Can. Entomol. 1962, 94, 1103-1107. [CrossRef]

31. Mrkva, R. Bionomie píd'alky podzimní (Operophtera brumata L.)—Motýl a vajíčko. Acta Univ. Agric. (Brno) Ser. C 1968, 37, 223-246. (In Czech)

32. Edland, T. Wind dispersal of the winter moth larvae Operophtera brumata L. (Lep., Geometridae) and its relevance to control measures. Nor. Entomol. Tidsskr. 1971, 18, 103-107.

33. Leonard, D.E. Air-borne dispersal of larvae of the gypsy moth and its influence on concepts of control. J. Econ. Entomol. 1971, 64, 638-641. [CrossRef]

34. West, C. The Effects on Phytophagous Insects of Variation in Defence Mechanisms within a Plant. Ph.D. Thesis, University of Oxford, Oxford, UK, 1985.

35. Barbosa, P.; Krischik, V.; Lance, D. Life-history traits of forest-inhabiting flightless Lepidoptera. Am. Midl. Nat. 1989, 122, 262-274. [CrossRef]

36. Tammaru, T.; Kaitaniemi, P.; Ruohomäki, K. Oviposition choices of Epirrita autumnata (Lepidoptera: Geometridae) in relation to its eruptive population dynamics. Oikos 1995, 74, 296-304. [CrossRef]

37. Diss, A.L.; Kunkel, J.G.; Montgomery, M.E.; Leonard, D.E. Effects of maternal nutrition and egg provisioning on parameters of larval hatch, survival and dispersal in the gypsy moth, Lymantria dispar L. Oecologia 1996, 106, 470-477. [CrossRef]

38. Elkinton, J.; Boettner, G.; Liebhold, A.; Gwiazdowski, R. Biology, Spread, and Biological Control of Winter Moth in the Eastern United States; FHTET-2014-07; U.S. Department of Agriculture, Forest Service, Forest Health Technology Team: Morgantown, WV, USA, 2015; p. 22. Available online: https://www.fs.fed.us/nrs/pubs/jrnl/2015/fhtet-2014-07_elkinton_2015_001.pdf (accessed on 17 March 2019).

39. Murakami, M.; Wada, N. Difference in leaf quality between canopy trees and seedlings affects migration and survival of spring-feeding moth larvae. Can. J. For. Res. 1997, 27, 1351-1356. [CrossRef]

40. Torres-Vila, L.M.; Stockel, J.; Roehrich, R.; Rodríguez-Molina, M.C. The relation between dispersal and survival of Lobesia botrana larvae and their density in vine inflorescences. Entomol. Exp. Appl. 1997, 84, 109-114. [CrossRef]

41. Sugiura, S.; Yamazaki, K. The role of silk threads as lifelines for caterpillars: Pattern and significance of lifeline-climbing behaviour. Ecol. Entomol. 2006, 31, 52-57. [CrossRef]

42. Jones, R.E. Search Behaviour: A study of three caterpillar species. Behaviour 1977, 60, 237-259. [CrossRef]

43. Moore, R.; Warrington, S.; Whittaker, J.B. Herbivory by insects on oak trees in pure stands compared with paired mixtures. J. Appl. Ecol. 1991, 28, 290-304. [CrossRef]

44. Alalouni, U.; Brandl, R.; Auge, H.; Schädler, M. Does insect herbivory on oak depend on the diversity of tree stands? Basic Appl. Ecol. 2014, 15, 685-692. [CrossRef]

45. Bognounou, F.; De Grandpré, L.; Pureswaran, D.S.; Kneeshaw, D. Temporal variation in plant neighborhood effects on the defoliation of primary and secondary hosts by an insect pest. Ecosphere 2017, 8, e01759. [CrossRef]

46. Castagneyrol, B.; Giffard, B.; Péré, C.; Jactel, H. Plant apparency, an overlooked driver of associational resistance to insect herbivory. J. Ecol. 2013, 101, 418-429. [CrossRef]

47. Castagneyrol, B.; Giffard, B.; Valdés-Correcher, E.; Hampe, A. Tree diversity effects on leaf insect damage on pedunculate oak: The role of landscape context and forest stratum. For. Ecol. Manag. 2019, 433, 287-294. [CrossRef]

48. Guyot, V.; Jactel, H.; Imbaud, B.; Burnel, L.; Castagneyrol, B.; Heinz, W.; Deconchat, M.; Vialatte, A. Tree diversity drives associational resistance to herbivory at both forest edge and interior. Ecol. Evol. 2019, 9, 9040-9051. [CrossRef] [PubMed] 
49. Damestoy, T.; Jactel, H.; Belouard, T.; Schmuck, H.; Plomion, C.; Castagneyrol, B. Tree species identity and forest composition affect the number of oak processionary moth captured in pheromone traps and the intensity of larval defoliation. Agric. For. Entomol. 2020, 22, 169-177. [CrossRef]

50. Barbosa, P.; Hines, J.; Kaplan, I.; Martinson, H.; Szczepaniec, A.; Szendrei, Z. Associational resistance and associational susceptibility: Having right or wrong neighbors. Annu. Rev. Ecol. Evol. Syst. 2009, 40, 1-20. [CrossRef]

51. Jactel, H.; Brockerhoff, E.G. Tree diversity reduces herbivory by forest insects. Ecol. Lett. 2007, 10, 835-848. [CrossRef]

52. Guyot, V.; Castagneyrol, B.; Vialatte, A.; Deconchat, M.; Jactel, H. Tree diversity reduces pest damage in mature forests across Europe. Biol. Lett. 2016, 12, 20151037. [CrossRef] [PubMed]

53. Jactel, H.; Moreira, X.; Castagneyrol, B. Tree diversity and forest resistance to insect pests: Patterns, mechanisms and prospects. Annu. Rev. Entomol. 2020, 66, 277-296. [CrossRef]

54. Vehviläinen, H.; Koricheva, J.; Ruohomäki, K. Tree species diversity influences herbivore abundance and damage: Meta-analysis of long-term forest experiments. Oecologia 2007, 152, 287-298. [CrossRef] [PubMed]

55. Setiawan, N.N.; Vanhellemont, M.; Baeten, L.; Dillen, M.; Verheyen, K. The effects of local neighbourhood diversity on pest and disease damage of trees in a young experimental forest. For. Ecol. Manag. 2014, 334, 1-9. [CrossRef]

56. Moreira, X.; Glauser, G.; Abdala-Roberts, L. Interactive effects of plant neighbourhood and ontogeny on insect herbivory and plant defensive traits. Sci. Rep. 2017, 7, 1-9. [CrossRef]

57. Van Schrojenstein Lantman, I.M.; Hertzog, L.R.; Vandegehuchte, M.L.; Martel, A.; Verheyen, K.; Lens, L.; Bonte, D. Leaf herbivory is more impacted by forest composition than by tree diversity or edge effects. Basic Appl. Ecol. 2018, 29, 79-88. [CrossRef]

58. Underwood, N.; Inouye, B.D.; Hambäck, P.A. A conceptual framework for associational effects: When do neighbors matter and how would we know? Q. Rev. Biol. 2014, 89, 1-19. [CrossRef]

59. Moreira, X.; Abdala-Roberts, L.; Rasmann, S.; Castagneyrol, B.; Mooney, K.A. Plant diversity effects on insect herbivores and their natural enemies: Current thinking, recent findings, and future directions. Curr. Opin. Insect. Sci. 2016, 14, 1-7. [CrossRef] [PubMed]

60. Nealis, V.G.; Régnière, J. Insect host relationships influencing disturbance by the spruce budworm in a boreal mixedwood forest. Can. J. For. Res. 2004, 34, 1870-1882. [CrossRef]

61. Schafellner, C.; Kramer, W.; Schopf, A. Three trophic level interaction: The influence of host plants on the performance of gypsy moth (Lymantria dispar) and its parasitoid, Glyptapanteles liparidis (Hymenoptera, Braconidae). IOBC WPRS Bull. 2005, 28, 193-200.

62. Korpel', Š. Die Urwälder der Westkarpaten, 1st ed.; Fischer Verlag: Stuttgart, Germany, 1995; p. 310.

63. Wesołowski, T.; Rowiński, P. Tree defoliation by winter moth Operophtera brumata L. during an outbreak affected by structure of forest landscape. For. Ecol. Manag. 2006, 221, 299-305. [CrossRef]

64. Wesołowski, T.; Rowiński, P. Timing of bud burst and tree-leaf development in a multispecies temperate forest. For. Ecol. Manag. 2006, 237, 387-393. [CrossRef]

65. Vitasse, Y.; Delzon, S.; Dufrêne, E.; Pontailler, J.Y.; Louvet, J.M.; Kremer, A.; Michalet, R. Leaf phenology sensitivity to temperature in European trees: Do within-species populations exhibit similar responses? Agric. For. Meteorol. 2009, 149, 735-744. [CrossRef]

66. Pividori, M.; Giannetti, F.; Barbati, A.; Chirici, G. European forest types: Tree species matrix. In European Atlas of Forest Tree Species, 1st ed.; San-Miguel-Ayanz, J., de Rigo, D., Caudullo, G., Houston Durrant, T., Mauri, A., Eds.; Publications Office of the European Union: Luxembourg, 2016; pp. 34-35.

67. Cole, E.F.; Sheldon, B.C. The shifting phenological landscape: Within and between-species variation in leaf emergence in a mixed-deciduous woodland. Ecol. Evol. 2017, 7, 1135-1147. [CrossRef]

68. Van Dongen, S.; Backeljau, T.; Matthysen, E.; Dhondt, A.A. Effects of forest fragmentation on the population structure of the winter moth Operophtera brumata L. (Lepidoptera. Geometridae). Acta Oecol. 1994, 15, 193-206.

69. Tscharntke, T.; Brandl, R. Plant-insect interactions in fragmented landscapes. Annu. Rev. Entomol. 2004, 49, 405-430. [CrossRef]

70. Rossetti, M.R.; Tscharntke, T.; Aguilar, R.; Batáry, P. Responses of insect herbivores and herbivory to habitat fragmentation: A hierarchical meta-analysis. Ecol. Lett. 2017, 20, 264-272. [CrossRef]

71. Pereira, P.F.; Lourenço, R.; Lopes, C.; Oliveira, A.; Ribeiro-Silva, J.; Rabaça, J.E.; Pinto-Correia, T.; Figueiredo, D.; Mira, A.; Marques, J.T. The influence of management and environmental factors on insect attack on cork oak canopy. For. Ecol. Manag. 2019, 453, 117582. [CrossRef]

72. Van Dongen, S.; Scott, T. Effects of forest fragmentation and local habitat structure on densities of winter moth (Operophtera brumata L.). Belg. J. Zool. 2002, 132, 165-170.

73. Summerville, K.S.; Crist, T.O. Determinants of lepidopteran community composition and species diversity in eastern deciduous forests: Roles of season, eco-region and patch size. Oikos 2003, 100, 134-148. [CrossRef]

74. Summerville, K.S.; Crist, T.O. Contrasting effects of habitat quantity and quality on moth communities in fragmented landscapes. Ecography 2004, 27, 3-12. [CrossRef]

75. Ewers, R.M.; Didham, R.K. Confounding factors in the detection of species responses to habitat fragmentation. Biol. Rev. 2006, 81, 117-142. [CrossRef]

76. Schmidt, N.B.C.; Roland, J. Moth diversity in a fragmented habitat: Importance of functional groups and landscape scale in the boreal forest. Ann. Entomol. Soc. Am. 2006, 99, 1110-1120. [CrossRef]

77. Valdés-Correcher, E.; Van Halder, I.; Barbaro, L.; Castagneyrol, B.; Hampe, A. Insect herbivory and avian insectivory in novel native oak forests: Divergent effects of stand size and connectivity. For. Ecol. Manag. 2019, 445, 146-153. [CrossRef] 
78. Viswanathan, A.; Ghazoul, J.; Lewis, O.; Honwad, G.; Bagchi, R. Effects of forest fragment area on interactions between plants and their natural enemies: Consequences for plant diversity at multiple spatial scales. Front. For. Glob. Chang. 2019, 2, 88. [CrossRef]

79. Csóka, G.; Szabóky, C. Checklist of herbivorous insects of native and exotic oaks in Hungary I (Lepidoptera). Acta Silv. Lign. Hung. 2005, 1, 59-72.

80. Patočka, J.; Kulfan, J. Lepidoptera of Slovakia: Bionomics and Ecology/Motýle Slovenska: Bionómia a Ekológia, 1st ed.; VEDA: Bratislava, Slovakia, 2009; p. 312.

81. Goliašová, K.; Michalková, E. Flóra Slovenska V/3 [The Flora of Slovakia V/3], 1st ed.; VEDA: Bratislava, Slovakia, 2006 ; p. 344.

82. Patočka, J. Húsenice na Duboch v ČSR [Caterpillars on oaks in Czechoslovakia], 1st ed.; Štátne Pôdohospodárske Nakladatel'stvo: Bratislava, Czechoslovakia, 1954; p. 264.

83. Bergmeier, E.; Petermann, J.; Schröder, E. Geobotanical survey of wood-pasture habitats in Europe: Diversity, threats and conservation. Biodivers. Conserv. 2010, 19, 2995-3014. [CrossRef]

84. Ádám, R.; Ódor, P.; Bölöni, J. The effects of stand characteristics on the understory vegetation in Quercus petraea and Q. cerris dominated forests. Community Ecol. 2013, 14, 101-109. [CrossRef]

85. Gallé, A.; Haldimann, P.; Feller, U. Photosynthetic performance and water relations in young pubescent oak (Quercus pubescens) trees during drought stress and recovery. New Phytol. 2007, 174, 799-810. [CrossRef] [PubMed]

86. Roloff, A.; Korn, S.; Gillner, S. The Climate-Species-Matrix to select tree species for urban habitats considering climate change. Urban For. Urban Green. 2009, 8, 295-308. [CrossRef]

87. Kätzel, R.; Becker, F.; Schröder, J.; Glatthorn, J.; Höltken, A.; Löffler, S. Flaum-und Zerr-Eiche in Brandenburg-Alternative Baumarten im Klimawandel? [Downy oak and Turkey oak in Brandenburg-Alternative Tree Species in Climate Change?]. Wissenstransfer Die Prax. 2012, 49, 23-36. Available online: http:/ / webdoc.sub.gwdg.de/ebook/serien/yo/EfS/49.pdf\#page=24 (accessed on 28 April 2019). (In German).

88. De Rigo, D.; Enescu, C.M.; Houston Durrant, T.; Caudullo, G. Quercus cerris in Europe: Distribution, habitat, usage and threats. In European Atlas of Forest Tree Species, 1st ed.; San-Miguel-Ayanz, J., de Rigo, D., Caudullo, G., Houston Durrant, T., Mauri, A., Eds.; Publications Office of the European Union: Luxembourg, 2016; pp. 148-149. Available online: https: //ies-ows.jrc.ec.europa.eu/efdac/download/Atlas/pdf/Quercus_cerris.pdf (accessed on 14 April 2019).

89. Reif, A.; Xystrakis, F.; Gärtner, S.; Sayer, U. Floristic change at the drought limit of European beech (Fagus sylvatica L.) to Downy oak (Quercus pubescens) forest in the temperate climate of Central Europe. Not. Bot. Horti Agrobot. Cluj Napoca 2017, 45, 646-654. [CrossRef]

90. Früchtenicht, E.; Neumann, L.; Klein, N.; Bonal, D.; Brüggemann, W. Response of Quercus robur and two potential climate change winners-Quercus pubescens and Quercus ilex-To two years summer drought in a semi-controlled competition study: I-Tree water status. Environ. Exp. Bot. 2018, 152, 107-117. [CrossRef]

91. Mevy, J.-P.; Loriod, B.; Liu, X.; Corre, E.; Torres, M.; Büttner, M.; Haguenauer, A.; Reiter, I.M.; Fernandez, C.; Gauquelin, T. Response of Downy oak (Quercus pubescens Willd.) to climate change: Transcriptome assembly, differential gene analysis and targeted metabolomics. Plants 2020, 9, 1149. [CrossRef]

92. Hlásny, T.; Holuša, J.; Štěpánek, P.; Turčáni, M.; Polčák, N. Expected impacts of climate change on forests: Czech Republic as a case study. J. For. Sci. 2011, 57, 422-431. [CrossRef]

93. Rubtsov, V.V.; Utkina, I.A. Long-term dynamics of Operophtera brumata L. in the oak stands of forest-steppe. Contemp. Probl. Ecol. 2011, 4, 777-783. [CrossRef]

94. Wada, N.; Murakami, M.; Yoshida, K. Effects of herbivore-bearing adult trees of the oak Quercus crispula on the survival of their seedlings. Ecol. Res. 2000, 15, 219-227. [CrossRef]

95. Bochníček, O.; Hrušková, K.; Zvara, I. Klimatický atlas Slovenska/Climate Atlas of Slovakia, 1st ed.; Slovenský Hydrometeorologický ústav: Bratislava, Slovak, 2015; p. 131.

96. Basset, Y.; Springate, N.D.; Aberlenc, H.P.; Delvare, G. A review of methods for sampling arthropods in tree canopies. In Canopy Arthropods, 1st ed.; Stork, N.E., Adis, J., Didham, R.K., Eds.; Chapman \& Hall: London, UK, 1997; pp. $27-52$.

97. Lepidoptera and Their Ecology. Available online: www.pyrgus.de (accessed on 15 July 2016).

98. Lepiforum: Bestimmung von Schmetterlingen (Lepidoptera) und Ihren Präimaginalstadien [Lepiforum: Identification of Butterflies and Moths (Lepidoptera) and Their Preimaginal Stages]. Available online: http:/ /lepiforum.org/wiki (accessed on 10 July 2016).

99. Pastorális, G.; Kalivoda, H.; Panigaj, L'. Zoznam motýl'ov (Lepidoptera) zistených na Slovensku. [Checklist of Lepidoptera recorded in Slovakia]. Folia Faun. Slov. 2013, 18, 101-232. Available online: http:/ / www.ffs.sk/pdf/FFS-18-15-Pastoralis-et-al-20 13.pdf (accessed on 28 April 2019).

100. Anderson, M.J. A new method for non-parametric multivariate analysis of variance. Austral Ecol. 2001, 26, 32-46. [CrossRef]

101. Bray, J.R.; Curtis, J.T. An ordination of the upland forest communities of southern Wisconsin. Ecol. Monogr. 1957, 27, 325-349. [CrossRef]

102. Kruskal, J.B. Multidimensional scaling by optimizing goodness of fit to a nonmetric hypothesis. Psychometrika 1964, $29,1-27$. [CrossRef]

103. R Core Team. R: A Language and Environment for Statistical Computing; R Core Team: Vienna, Austria, 2019; Available online: https:/ / www.R-project.org/ (accessed on 6 December 2019). 
104. Canty, A.; Ripley, B. Boot: Bootstrap R (S-Plus) Functions. R Package. Version 1.3-18. Available online: https:/ / cran.r-project. org/web/packages/boot/index.html (accessed on 19 December 2019).

105. Wickham, H. Ggplot2: Elegant Graphics for Data Analysis, 2nd ed.; Springer: New York, NY, USA, 2016; p. 260. [CrossRef]

106. Venables, W.N.; Ripley, B.D. Modern Applied Statistics with S, 4th ed.; Springer: New York, NY, USA, 2002; p. 498. [CrossRef]

107. Hothorn, T.; Bretz, F.; Westfall, P. Simultaneous inference in general parametric models. Biom. J. 2008, 50, 346-363. [CrossRef] [PubMed]

108. Oksanen, J.; Blanchet, F.G.; Friendly, M.; Kindt, R.; Legendre, P.; McGlinn, D.; Minchin, P.R.; O’Hara, R.B.; Simpson, G.L.; Solymos, P.; et al. Vegan: Community Ecology Package. R Package. Version 2.5-4. Available online: https://CRAN.R-project.org/package= vegan (accessed on 12 December 2019).

109. Kulfan, J. Zur Struktur und Saisondynamik von Raupenzönosen (Lepidoptera) an Eichen [On the structure and seasonal dynamics of the caterpillar communities (Lepidoptera) on oaks]. Biologia (Bratislava) 1992, 47, 653-661. (In German)

110. Kulfan, M.; Holecová, M.; Fajčík, J. Caterpillar (Lepidoptera) communities on European Turkey oak (Quercus cerris) in Malé Karpaty Mts (SW Slovakia). Biologia 2006, 61, 573-578. [CrossRef]

111. Ovcharov, D.; Dojchev, D.; Todorov, A. Differences in attack from leaf chewing pests (families Tortricidae and Geometridae, order Lepidoptera) by some Quercus species. In Lesotekhnicheski Universitet. Yubileen Sbornik Nauchni Dokladi: 75 Godini Visshe Lesotekhnichesko Obrazovanie v Blgariya. Sektsiya Ekologiya i Opazvane na Okolnata Sreda; University of Forestry: Sofia, Bulgaria, 2000; pp. 269-278.

112. Gripenberg, S.; Morriën, E.; Cudmore, A.; Salminen, J.P.; Roslin, T. Resource selection by female moths in a heterogeneous environment: What is a poor girl to do? J. Anim. Ecol. 2007, 76, 854-865. [CrossRef]

113. Holliday, N.J. Population ecology of winter moth (Operophtera brumata) on apple in relation to larval dispersal and time of bud burst. J. Appl. Ecol. 1977, 14, 803-813. [CrossRef]

114. Graf, B.; Borer, F.; Höpli, H.U.; Hohn, H.; Dorn, S. The winter moth Operophtera brumata L. (Lep., Geometridae) on apple and cherry: Spatial and temporal aspects of recolonization in autumn. J. Appl. Entomol. 1995, 119, 295-301. [CrossRef]

115. Tiberi, R.; Benassai, D.; Niccoli, A. Influence of different host plants on the biology and behaviour of the green oak leaf roller, Tortrix viridana L.: First results. IOBC/WPRS Bull. 2005, 28, 211-217. Available online: https://www.iobc-wprs.org/pub/ bulletins /iobc-wprs_bulletin_2005_28_08.pdf\#page=231 (accessed on 28 April 2019).

116. Capinera, J.L.; Barbosa, P. Dispersal of first-instar gypsy moth larvae in relation to population quality. Oecologia 1976, $26,53-64$. [CrossRef] [PubMed]

117. Zalucki, M.P.; Clarke, A.R.; Malcolm, S.B. Ecology and behavior of first instar larval Lepidoptera. Annu. Rev. Entomol. 2002, 47, 361-393. [CrossRef]

118. Lance, D.; Barbosa, P. Host tree influences on the dispersal of first instar gypsy moth, Lymantria dispar. Oikos 1982, 38, 1-7. [CrossRef]

119. Liebhold, A.M.; Elkinton, J.S.; Wallner, W.E. Effect of burlap bands on between-tree movement of late-instar gypsy moth, Lymantria dispar (Lepidoptera: Lymantriidae). Environ. Entomol. 1986, 15, 373-379. [CrossRef]

120. Doane, C.; Leonard, D. Orientation and dispersal of late-stage larvae of Porthetria dispar (Lepidoptera: Lymantriidae). Can. Entomol. 1975, 107, 1333-1338. [CrossRef]

121. Humphrey, J.W.; Swaine, M.D. Factors affecting the natural regeneration of Quercus in Scottish oakwoods. II. Insect defoliation of trees and seedlings. J. Appl. Ecol. 1997, 34, 585-593. [CrossRef]

122. Hajek, A. Larval behavior in Lymantria dispar increases risk of fungal infection. Oecologia 2001, 126, 285-291. [CrossRef] [PubMed]

123. Greeney, H.F.; Dyer, L.A.; Smilanich, A.M. Feeding by lepidopteran larvae is dangerous: A review of caterpillars' chemical, physiological, morphological, and behavioral defenses against natural enemies. Invertebr. Surviv. J. 2012, 9, 7-34. Available online: https://www.isj.unimore.it/index.php/ISJ/article/view/256/171 (accessed on 28 April 2019).

124. Pepi, A.A.; Broadley, H.J.; Elkinton, J.S. Density-dependent effects of larval dispersal mediated by host plant quality on populations of an invasive insect. Oecologia 2016, 182, 499-509. [CrossRef]

125. Humphreys, R.K.; Ruxton, G.D. Dropping to escape: A review of an under-appreciated antipredator defence. Biol. Rev. 2019, 94, 575-589. [CrossRef]

126. Wittman, J.T.; Aukema, B.H. Foliage type and deprivation alters the movement behavior of late instar European gypsy moth Lymantria dispar (Lepidoptera: Erebidae). J. Insect Behav. 2019, 32, 24-37. [CrossRef]

127. Southwood, T.R.E. Migration of terrestrial arthropods in relation to habitat. Biol. Rev. 1962, 37, 171-211. [CrossRef]

128. Mitchell, R.G. Dispersal of early instars of the Douglas-fir tussock moth. Ann. Entomol. Soc. Am. 1979, 72, 291-297. [CrossRef]

129. Tikkanen, O.-P.; Woodcock, B.; Watt, A.; Lock, K. Are polyphagous geometrid moths with flightless females adapted to budburst phenology of local host species? Oikos 2006, 112, 83-90. [CrossRef]

130. van Asch, M.; Salis, L.; Holleman, L.J.M.; van Lith, B.; Visser, M.E. Evolutionary response of the egg hatching date of a herbivorous insect under climate change. Nat. Clim. Chang. 2013, 3, 244-248. [CrossRef]

131. Hagstrum, D.W.; Subramanyam, B. Immature insects: Ecological roles of mobility. Am. Entomol. 2010, 56, 230-241. [CrossRef]

132. Vindstad, O.P.L.; Jepsen, J.U.; Yoccoz, N.G.; Bjørnstad, O.N.; Mesquita, M.D.S.; Ims, R.A. Spatial synchrony in sub-arctic geometrid moth outbreaks reflects dispersal in larval and adult life cycle stages. J. Anim. Ecol. 2019, 88, 1134-1145. [CrossRef]

133. Saunders, D.A.; Hobbs, R.J.; Margules, C.R. Biological consequences of ecosystem fragmentation: A review. Conserv. Biol. 1991, 5, 18-32. [CrossRef] 
134. Ozanne, C.M.P.; Speight, M.R.; Hambler, C.; Evans, H.F. Isolated trees and forest patches: Patterns in canopy arthropod abundance and diversity in Pinus sylvestris (Scots Pine). For. Ecol. Manag. 2000, 137, 53-63. [CrossRef]

135. Maleque, M.A.; Ishii, H.T.; Maeto, K. The use of arthropods as indicators of ecosystem integrity in forest management. J. For. 2006, 104, 113-117. [CrossRef]

136. Bernaschini, M.L.; Trumper, E.; Valladares, G.; Salvo, A. Are all edges equal? Microclimatic conditions, geographical orientation and biological implications in a fragmented forest. Agric. Ecosyst. Environ. 2019, 280, 142-151. [CrossRef]

137. Fortin, M.; Mauffette, Y. Forest edge effects on the biological performance of the forest tent caterpillar (Lepidoptera: Lasiocampidae) in sugar maple stands. Ecoscience 2001, 8, 164-172. [CrossRef]

138. Wirth, R.; Meyer, S.T.; Leal, I.R.; Tabarelli, M. Plant herbivore interactions at the forest edge. In Progress in Botany, 1st ed.; Lüttge, U., Beyschlag, W., Murata, J., Eds.; Springer: Berlin/Heidelberg, Germany, 2008; Volume 69, pp. 423-448. [CrossRef]

139. White, P.J.; McGill, B.J.; Lechowicz, M.J. Human-disturbance and caterpillars in managed forest fragments. Biodivers. Conserv. 2011, 20, 1745-1762. [CrossRef]

140. Maldonado-López, Y.; Cuevas-Reyes, P.; Stone, G.N.; Nieves-Aldrey, J.L.; Oyama, K. Gall wasp community response to fragmentation of oak tree species: Importance of fragment size and isolated trees. Ecosphere 2015, 6, 31. [CrossRef]

141. Macek, J.; Dvořák, J.; Traxler, L.; Červenka, V. Motýli a housenky střední Evropy. Noční motýli II.—Mưrovití. [Butterflies and Caterpillars of Central Europe. Moths II.-Noctuidae], 1st ed.; Academia: Praha, Czech, 2008; p. 490. (In Czech)

142. Hausmann, A.; Viidalepp, J. The Geometrid Moths of Europe, 1st ed.; Apollo Books: Stenstrup, Denmark, 2012 ; Volume 3, p. 743.

143. Müller, B.; Erlacher, S.; Hausmann, A.; Rajaei, H.; Sihvonen, P.; Skou, P. The Geometrid Moths of Europe. Volume 6: Ennominae II, 1st ed.; E.J. Brill: Leiden, The Netherlands; Boston, MA, USA, 2019; p. 906.

144. Mitchell, C.; Brennan, R.M.; Cross, J.V.; Johnson, S.N. Arthropod pests of currant and gooseberry crops in the UK: Their biology, management and future prospects. Agric. For. Entomol. 2011, 13, 221-237. [CrossRef]

145. Stancă-Moise, C. A study about the pest insects in the apple trees orchards, with local sorts, specific to Sibiel village (Sibiu county), in the conditions of the years 2015-2016. Sci. Pap. Ser. Manag. Econom. Eng. Agric. Rural Dev. 2017, 17, 379-383.

146. Offenberg, J.; Nielsen, J.S.; Damgaard, C. Wood ant (Formica polyctena) services and disservices in a Danish apple plantation. Sociobiology 2019, 66, 247-256. [CrossRef]

147. Samnegård, U.; Alins, G.; Boreux, V.; Bosch, J.; García, D.; Happe, A.K.; Klein, A.-M.; Miñarro, M.; Mody, K.; Porcel, M.; et al. Management trade-offs on ecosystem services in apple orchards across Europe: Direct and indirect effects of organic production. J. Appl. Ecol. 2019, 56, 802-811. [CrossRef]

148. Adamska, I.; Dziegielewska, M. Colonization of selected rose varieties by pests and pathogens. Folia Pomer. Univ. Technol. Stetin. Agric. Aliment. Pisc. Zootech. 2016, 330, 7-17. [CrossRef]

149. Dziegielewska, M.; Adamska, I. The health of the forest stand along urban routes of different traffic intensity in Szczecin. Prog. Plant Prot. 2016, 56, 191-198. (In Polish)

150. White, J.A.; Whitham, T.G. Associational susceptibility of cottonwood to a box elder herbivore. Ecology 2000, 81, 1795-1803. [CrossRef]

151. Plath, M.; Dorn, S.; Riedel, J.; Barrios, H.; Mody, K. Associational resistance and associational susceptibility: Specialist herbivores show contrasting responses to tree stand diversification. Oecologia 2012, 169, 477-487. [CrossRef] [PubMed]

152. Ebert, G.; Steiner, A.; Trusch, R. Ennominae (Geometridae). In Die Schmetterlinge Baden-Württembergs, 1st ed.; Ebert, G., Ed.; Verlag Eugen Ulmer: Stuttgart, Germany, 2003; Volume 9-Nachtfalter VII, pp. 294-579.

153. Szabó, S.; Árnyas, E.M.; Tóthmérész, B.; Varga, Z. Long-term light trap study on the macro-moth (Lepidoptera: Macroheterocera) fauna of the Aggtelek National Park. Acta Zool. Acad. Sci. Hung. 2007, 53, 257-269.

154. Kulfan, J.; Sarvašová, L.; Parák, M.; Zach, P. Effects of a host tree on movement and distribution of winter geometrid moths (Lepidoptera): Thickness of trunks and branches. Folia Oecol. 2019, 46, 83-90. [CrossRef]

155. Shutt, J.D.; Burgess, M.D.; Phillimore, A.B. A spatial perspective on the phenological distribution of the spring woodland caterpillar peak. Am. Nat. 2019, 194, E109-E121. [CrossRef]

156. Bussotti, F.; Borghini, F.; Celesti, C.; Leonzio, C.; Bruschi, P. Leaf morphology and macronutrients in broadleaved trees in central Italy. Trees 2000, 14, 361-368. [CrossRef]

157. Velichkova Wolkerstorfer, S.; Wonisch, A.; Stankova, T.; Tsvetkova, N.; Tausz, M. Seasonal variations of gas exchange, photosynthetic pigments, and antioxidants in Turkey oak (Quercus cerris L.) and Hungarian oak (Quercus frainetto Ten.) of different age. Trees 2011, 25, 1043-1052. [CrossRef]

158. Neuvonen, S.; Haukioja, E.; Molarius, A. Delayed inducible resistance against a leaf-chewing insect in four deciduous tree species. Oecologia 1987, 74, 363-369. [CrossRef]

159. Zúbrik, M.; Kunca, A.; Kulfan, J.; Rell, S.; Nikolov, C.; Galko, J.; Vakula, J.; Gubka, A.; Leontovyč, R.; Konôpka, B.; et al. Occurrence of gypsy moth (Lymantria dispar L.) in the Slovak Republic and its outbreaks during 1945-2020. Cent. Eur. For. J. 2021, 67, 55-71. [CrossRef]

160. Visser, M.E.; Holleman, L.J. Warmer springs disrupt the synchrony of oak and winter moth phenology. Proc. R. Soc. B 2001, 268, 289-294. [CrossRef]

161. Marçais, B.; Desprez-Loustau, M.L. European oak powdery mildew: Impact on trees, effects of environmental factors, and potential effects of climate change. Ann. For. Sci. 2014, 71, 633-642. [CrossRef] 